\title{
Diel vertical migration behavior of Calanus finmarchicus and its influence on right and sei whale occurrence
}

\author{
Mark F. Baumgartner ${ }^{1, *}$, Nadine S. J. Lysiak ${ }^{1}$, Carrie Schuman ${ }^{2,3}$, \\ Juanita Urban-Rich ${ }^{2}$, Frederick W. Wenzel ${ }^{4}$ \\ ${ }^{1}$ Biology Department, Woods Hole Oceanographic Institution, Woods Hole, Massachusetts 02543, USA \\ ${ }^{2}$ Environmental Earth and Ocean Sciences Department, University of Massachusetts Boston, 100 Morrissey Boulevard, \\ Boston, Massachusetts 02125, USA \\ ${ }^{3}$ Provasoli-Guillard National Center for Culture of Marine Phytoplankton, Bigelow Laboratory for Ocean Sciences, \\ West Boothbay Harbor, Maine 04575, USA \\ ${ }^{4}$ National Oceanic and Atmospheric Administration, Northeast Fisheries Science Center, 166 Water Street, Woods Hole, \\ Massachusetts 02543, USA
}

\begin{abstract}
Diel vertical migration (DVM) by herbivorous copepods likely has a profound effect on the behavior and ecology of copepod predators. We characterized the DVM behavior of late-stage Calanus finmarchicus in the southwestern Gulf of Maine during the spring seasons of 2005 to 2007 , and investigated the influence of this behavior on the occurrence of zooplanktivorous baleen whales. On 5 occasions, we occupied an oceanographic station for 1 to 2 d and conducted (1) a half-hourly census of whales and (2) a half-hourly cast with an instrument package measuring temperature, salinity, chlorophyll fluorescence, and copepod abundance. We observed significant variability in DVM behavior both within and among years that was unrelated to stratification or chlorophyll concentration. Instead, DVM appeared to be influenced by the vertical distribution of phytoplankton, the presence of visual predators (sand lance Ammodytes spp.), copepod developmental stage, and the feeding history of individual copepods. Migrating copepods had oil sacs that were $44 \%$ larger than non-migrating copepods at the surface after accounting for developmental stage, which suggests that well-fed copepods are more likely to vertically migrate. While the occurrence of North Atlantic right whales Eubalaena glacialis was unrelated to variability in the migration behavior of C. finmarchicus, sei whales Balaenoptera borealis were significantly less abundant during times of strong DVM behavior. We speculate that right whales do not compete directly with sand lance and herring for C. finmarchicus, but by inducing DVM behavior, these fish are likely influencing the distribution and abundance of sei whales in the southwestern Gulf of Maine.
\end{abstract}

KEY WORDS: Calanus finmarchicus $\cdot$ Eubalaena glacialis $\cdot$ Balaenoptera borealis $\cdot$ Right whale Sei whale $\cdot$ Video plankton recorder · Optical plankton counter · Gulf of Maine

\section{INTRODUCTION}

The diel vertical migration (DVM) behavior of zooplankton has been studied for well over a century. Both observational and experimental studies in recent decades have offered compelling evidence for the theory that herbivorous zooplankton migrate downward out of the euphotic zone at dawn to avoid being eaten by visual predators, and they migrate upward into surface waters at dusk to graze on phytoplankton under the cover of night (e.g. Zaret \& Suffern 1976, Bollens \& Frost 1989, Dawidowicz et al. 1990). However, there appear to be many variations on these simple behavioral rules. For example, Hays (1995) and De Robertis 
et al. (2000) found that DVM behavior differs among zooplankton of varying size (both among and within species) based on their relative risk from size-selective visual predators. Zaret \& Kerfoot (1975) and Hays et al. (1994) also attributed differences in DVM behavior to pigmentation and body morphology, factors that affect detection by visual predators and escape speed, respectively. Ohman et al. (1983) observed reverse DVM by herbivorous copepods in response to normal DVM of their invertebrate predators. In some cases, DVM can cease altogether and zooplankton will remain at depth or at the surface during both day and night. While this may ultimately be related to predation risk (Bollens \& Frost 1989), several studies have suggested that an individual's feeding history can have a strong influence on DVM behavior (e.g. Huntley \& Brooks 1982, Dagg 1985, Hays et al. 2001). The mesocosm experiment of Huntley \& Brooks (1982) indicated that food limitation (i.e. starvation) causes copepods to abandon DVM by remaining in surface waters to graze, whereas Hays et al. (2001) suggested that wellfed copepods with sufficient energy reserves can survive for days at depth without vertically migrating.

There is growing interest in examining the influence of zooplankton DVM behavior on the distribution and behavior of predators (e.g. Bost et al. 2002, Hays 2003, Shepard et al. 2006, Baumgartner \& Fratantoni 2008). For large-bodied predators like baleen whales that need to feed on tremendous quantities of zooplankton each day (Kenney et al. 1986), DVM can have a profound effect on a predator's ability to find sufficient food resources and to exploit those resources efficiently. North Atlantic right whales Eubalaena glacialis visit the Great South Channel in the southwestern Gulf of Maine each spring to feed on highly concentrated aggregations of the calanoid copepod Calanus finmarchicus (CETAP 1982, Wishner et al. 1988, 1995). Sei whales Balaenoptera borealis are believed to only occasionally visit the inshore waters of the Gulf of Maine, including the Great South Channel, in response to increases in the availability of their copepod prey (Payne et al. 1990, Schilling et al. 1992); however, our recent springtime work in the Great South Channel (2004 to 2010) suggests that they are reasonably common in this area in most years (authors' pers. obs.). Winn et al. (1995) reported that right whale dive times in the Great South Channel were longer during the day and shorter at night when late-stage C. finmarchicus were exhibiting DVM behavior (Durbin et al. 1995a), and they hypothesized that right whales were feeding deep in the water column during the day and near the surface at night. The calling behavior of sei whales in this area also exhibits diel periodicity; Baumgartner \& Fratantoni (2008) found that sei whale calling rates increased during the day when vertically migrating $C$. finmarchicus were at depth, but decreased at night when $C$. finmarchicus had migrated to the surface. Baumgartner \& Fratantoni (2008) hypothesized that sei whales are unable to feed on deep layers of copepods, and that increased calling behavior during the day may be associated with a reduction in feeding on $C$. finmarchicus and either an increase in socializing with conspecifics or switching to a different prey species.

The vertical migration behavior of Calanus finmarchicus has been well studied in the North Atlantic (Falkenhaug et al. 1997, Fiksen \& Carlotti 1998, Beare \& McKenzie 1999, Emsley et al. 2005), including in the southwestern Gulf of Maine. Durbin et al. (1995a,b) investigated several aspects of $C$. finmarchicus ecology in the Great South Channel during the spring seasons of 1988 and 1989 as part of the South Channel Ocean Productivity Experiment (SCOPEX; Kenney \& Wishner 1995). Using net hauls in 3 depth strata, they observed no DVM during times when the spring bloom was underway or settling out (early May), strong DVM during the period immediately following the end of the bloom (mid-May), and persistent surface aggregations (i.e. no DVM) once stratification had been established (mid-May to early June). Based on ingestion rates measured during these vertical migration studies, Durbin et al. (1995b) suggested that C. finmarchicus is nearly always food-limited in the Great South Channel except during the spring bloom. Food limitation often causes a cessation of DVM behavior (Huntley \& Brooks 1982, Dagg 1985, Hays et al. 2001), but Durbin et al. (1995a) found both the presence and absence of DVM behavior during food-limiting conditions. While Durbin et al. (1995a) implicate stratification and food availability as having a strong influence on the observed patterns in this region, they also recognized that migration behavior may have been governed by the occurrence of predators.

The present study was conducted (1) to characterize the DVM behavior of Calanus finmarchicus in the Great South Channel during complementary studies of the biological and physical mechanisms promoting copepod aggregation in this region as well as right whale foraging behavior, (2) to investigate the factors influencing DVM behavior, and (3) to determine to what extent, if any, DVM behavior influences the occurrence of right and sei whales. Observations of copepod vertical distribution, whale abundance, and associated oceanographic conditions were collected at high temporal resolution at stations in the Great South Channel over a 1 to $2 \mathrm{~d}$ period on 5 separate occasions. DVM behavior was examined with respect to several extrinsic factors, including stratification and phytoplankton distribution and abundance. We also examined the role of feeding history on DVM behavior. 
Whereas Durbin et al. (1995a) used 'instantaneous' ingestion rates to assess food limitation, we assessed food limitation over longer time scales by estimating lipid reserves from in situ images of copepods. We hypothesized that well-fed C. finmarchicus (i.e. those with large oil sacs) are more likely to mitigate predation risk by vertically migrating than copepods with smaller lipid reserves (hypothesis H1). Finally, our observations of whale abundance were used to address the hypothesis that right and sei whales exhibit different responses to DVM by C. finmarchicus based on the observations of Winn et al. (1995) and Baumgartner \& Fratantoni (2008). Specifically, we anticipated that right whales are able to feed effectively on copepods regardless of whether they are aggregated at the surface (Mayo \& Marx 1990) or at depth (Baumgartner \& Mate 2003), whereas sei whales are unable to feed on deep migrating layers and are therefore less abundant during times of strong DVM (hypothesis H2).

\section{MATERIALS AND METHODS}

Sampling. The DVM behavior of Calanus finmarchicus was monitored on 5 occasions during the spring seasons of 2005 to 2007 in the Great South Channel of the southwestern Gulf of Maine (Fig. 1). On each occasion, the NOAA ship 'Albatross IV' occupied a geographically fixed oceanographic station in an area where numerous North Atlantic right whales were initially encountered (sei whale abundance was not considered in the selection of the station location). A vertical profiling instrument package was deployed at half-hour intervals for the entire time the station was occupied (21 to $37.5 \mathrm{~h}$; see Table 1 ). The instrument package consisted of a conductivity-temperaturedepth (CTD) instrument (SeaBird Electronics, SBE 19plus), a chlorophyll fluorometer (Wetlabs, WETStar WS3S), an optical plankton counter (OPC; Focal Technologies, OPC-1T; Herman 1988, 1992), a video plankton recorder (VPR; Seascan, AutoVPR in 2005, DAVPR in 2006 and 2007; Davis et al. 1992, 1996), an altimeter (Benthos, PSA-916), and a bottom contact switch (WHOI custom built), which provided vertical profiles of temperature (CTD), salinity (CTD), chlorophyll fluorescence (fluorometer), particle size and abundance (OPC), light attenuance (OPC), and zooplankton abundance and community composition (VPR). After drifting off the station during each cast with the vertical profiling instrument package, the ship would return to the station so that sampling could continue in the exact same geographic location.

Whale census. For 15 min during each half-hourly cast occurring during daylight hours, a team of 3 observers conducted a visual census of whales within 3

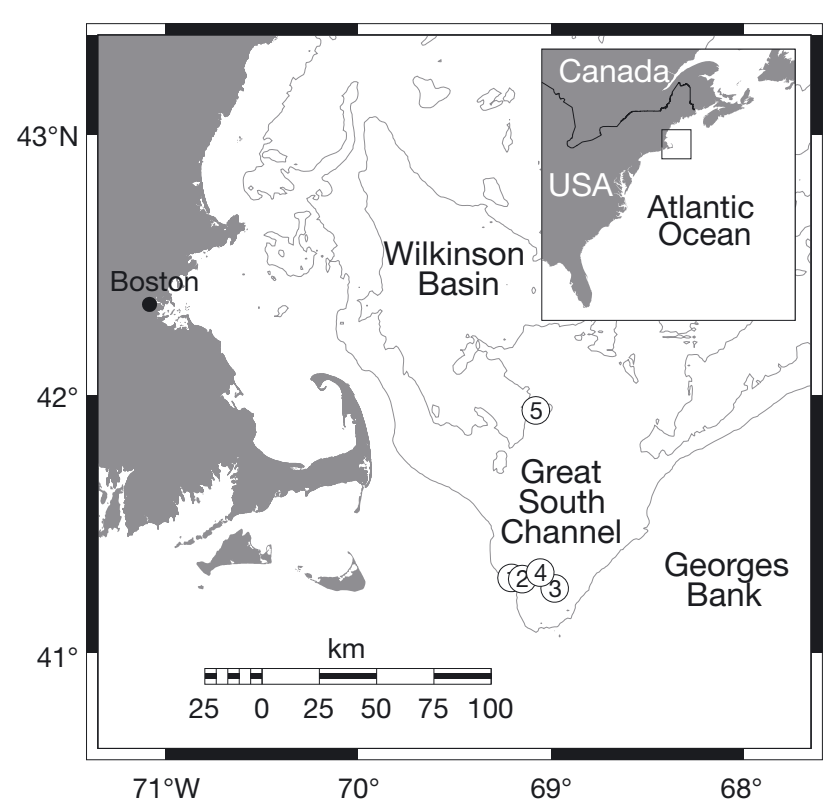

Fig. 1. Study area and oceanographic stations (1) to (5)) off the coast of Massachusetts

$\mathrm{km}$ of the ship using the naked eye and $10 \times 50$ binoculars. For each sighting, observers noted the species, the number of whales, the relative bearing and distance from the ship, and any overt behavioral information. Care was taken to identify and record individual whales only once during the 15 min census period. Whale abundance is hereinafter expressed as the number of whales seen per 15 min observation period.

Chlorophyll. Chlorophyll fluorescence can be used as a proxy for chlorophyll concentration (Lorenzen 1966), which in turn can be used as an indicator of phytoplankton abundance. To assess chlorophyll concentration and calibrate the fluorometer, seawater was collected at the stations occupied during 2007 using Niskin bottles attached to the sea cable just above the vertical profiling instrument package. Samples were obtained from the surface and at depth, typically near the pycnocline, the fluorescence maximum, or the maximum in OPC-derived Calanus finmarchicus abundance. Seawater was then filtered through Whatman GF/F filters (>0.7 $\mu \mathrm{m}$ particles), and the filters were wrapped in aluminum foil and frozen for later analysis. In the laboratory, chlorophyll was extracted in a $90 \%$ acetone solution, chilled in a freezer for $24 \mathrm{~h}$, allowed to come to room temperature, and analyzed on a calibrated Turner AU-10 fluorometer. Independent replicate measurements were made from each water sample to assess analytical error; replicate chlorophyll measurements were averaged to obtain a single chlorophyll measurement for each water sample. Measured in situ fluorescence was averaged within $\pm 1.5 \mathrm{~m}$ of the Niskin sampling depth. Voltage output from the 
WETStar instrument was converted first to an estimated chlorophyll concentration using the factory calibration, and then the field calibration described here was developed with and applied to these factorycalibrated values. This procedure allowed the application of a field calibration developed with the 2007 data only to be applied to fluorescence data from 2005 and 2006, since we expect seasonal phytoplankton communities and physiology to be roughly similar from year to year in this region. Only pairs of chlorophyll samples and averaged in situ fluorescence measurements collected simultaneously during nighttime or below $30 \mathrm{~m}$ during the daytime were used to develop a calibration equation. Surface samples collected during the daytime were omitted from comparison because of the well-known phenomenon of phytoplankton cells adapting to strong solar insolation by increasing photoprotective pigments and closing photosynthetic reaction centers, thereby reducing fluorescence (Dandonneau \& Neveux 1997, Laney et al. 2005). A calibration equation was developed using a simple linear regression forced through the origin.

Copepods. The VPR captures digital images of a small volume of water 23 to 30 times $\mathrm{s}^{-1}$, and is adept at estimating the abundance of large-bodied copepods such as Calanus finmarchicus. Regions of interest, defined as areas in the images with high brightness and contrast, were automatically extracted using AutoDeck software (Seascan) and visually inspected to identify and classify zooplankton. In 2006 and 2007, the oil sacs of late-stage $C$. finmarchicus were clearly visible in images captured with the high-magnification DAVPR (Fig. 2a). Prosome length and width and an outline of the oil sac were measured for a subset of copepods imaged by the VPR (Fig. 2b) using custom software written in IDL, a scientific programming environment (ITT Visual Information Solutions). Each copepod's orientation angle relative to the depth of field was estimated so that the length, width, and oil-sac outline could be transformed from the image's coordinate system to one in which the copepod is laterally exposed (i.e. laying flat on its side). Oil-sac volume was then estimated from the oil-sac outline using methods adapted from Miller et al. (2000) and described in Tarrant et al. (2008). All oil-sac volumes were log-transformed prior to statistical analysis. A prosome length threshold of $2.1 \mathrm{~mm}$ was used to distinguish between copepodid stages CIV $(<2.1 \mathrm{~mm})$ and $\mathrm{CV}(\geq 2.1 \mathrm{~mm})$ in the
VPR images (Campbell et al. 2001a, Tarrant et al. 2008). To verify the VPR-derived individual measurements, we compared lengths and oil-sac volumes estimated from the VPR during 2006 and 2007 to similar measurements on live CV copepodids collected at the surface in the same region during 2005 and 2006 (Tarrant et al. 2008, M. F. Baumgartner \& A. M. Tarrant unpubl. data). These copepods were live-sorted, staged on a depression slide, and photographed with a dissecting microscope (Wild M5 in 2005, Stemi 2000C in 2006) and an attached digital camera (Nikon Coolpix 5000 in 2005, Canon EOS-20D in 2006) (Fig. 2c), and prosome length, width, and oil-sac volume were measured and derived in a manner identical to that for the VPR (Fig. 2d). There was no evidence of differences between VPR-imaged copepods with lengths $\geq 2.1 \mathrm{~mm}$ prosome length (i.e. CV copepodids) and live-sorted CV copepodids for prosome length (mean difference $=0.020 \mathrm{~mm}, 2$-tailed $t$-test: $\mathrm{n}_{\mathrm{VPR}}=90$, $\mathrm{n}_{\text {live }}=100, t=0.866, \mathrm{p}=0.3877$ ) or oil-sac volume (2-tailed $t$-test: $\mathrm{n}_{\mathrm{VPR}}=90, \mathrm{n}_{\text {live }}=100, t=1.63, \mathrm{p}=0.1052$ ).

The volume of seawater imaged by the VPR is estimated as the product of the field of view and the depth of field. The field of view is fixed by the camera and was $10.5 \times 14 \mathrm{~mm}$ for the AutoVPR in 2005 and $7.5 \times$ $9.75 \mathrm{~mm}$ for the DAVPR in 2006 and 2007 (the userselectable DAVPR magnification setting was chosen specifically to provide high-magnification images of Calanus finmarchicus and is not appropriate for assessing the abundance of larger taxa, such as euphausiids or fish). The depth of field is the distance over which objects in a VPR image appear to be in

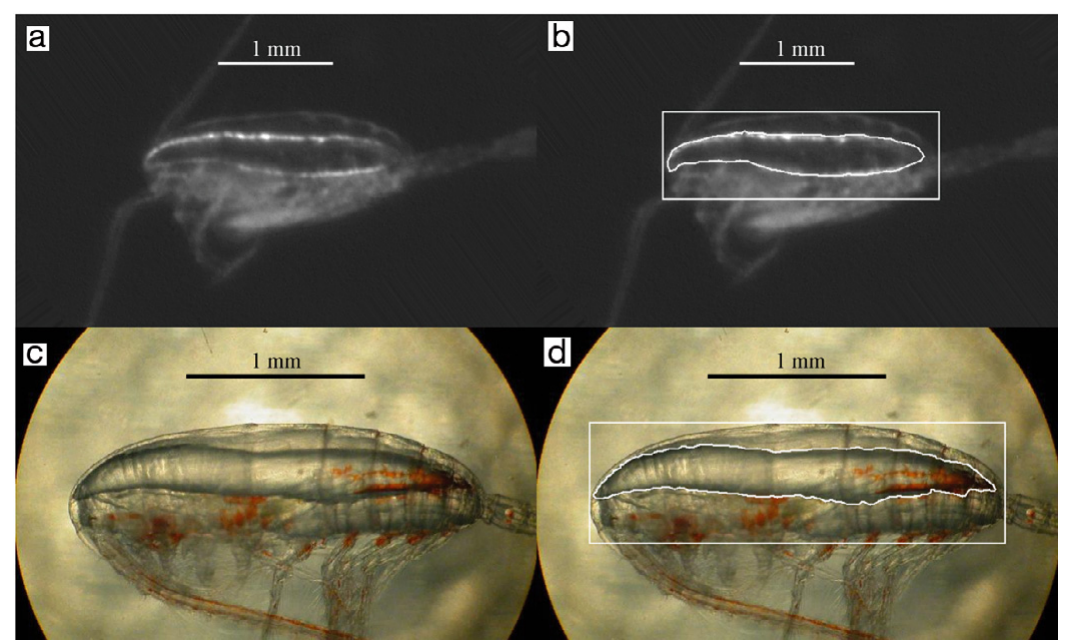

Fig. 2. Calanus finmarchicus. Two copepodids (stage CV) from the Great South Channel. (a) A copepod image from the video plankton recorder (model DAVPR), (b) the same copepod with the length, width, and oil-sac outline indicated. (c) A copepod captured with a zooplankton net by Tarrant et al. (2008), live-sorted, staged on a depression slide, and photographed under a dissecting microscope, (d) the same copepod with the length, width, and oil-sac outline indicated 
Table 1. Dates and locations of stations in the Great South Channel

\begin{tabular}{|c|c|c|c|c|}
\hline Stn & $\begin{array}{c}\text { Start date } \\
\text { and time (h) }\end{array}$ & Location & $\begin{array}{c}\text { Water } \\
\text { depth (m) }\end{array}$ & $\begin{array}{c}\text { Duration } \\
\text { (h) }\end{array}$ \\
\hline 1 & 18 May 05, 18:30 & $41^{\circ} 17.52^{\prime} \mathrm{N}, 69^{\circ} 12.22^{\prime} \mathrm{W}$ & 98 & 27.0 \\
\hline 2 & 7 May $06,14: 00$ & $41^{\circ} 17.24^{\prime} \mathrm{N}, 69^{\circ} 08.89^{\prime} \mathrm{W}$ & 103 & 21.0 \\
\hline 3 & 23 May 06, 16:00 & $41^{\circ} 15.06^{\prime} \mathrm{N}, 68^{\circ} 58.79^{\prime} \mathrm{W}$ & 137 & 34.5 \\
\hline 4 & 21 May 07, 19:30 & $41^{\circ} 18.76^{\prime} \mathrm{N}, 69^{\circ} 03.28^{\prime} \mathrm{W}$ & 160 & 37.5 \\
\hline 5 & 6 Jun $07,20: 30$ & $41^{\circ} 56.52^{\prime} \mathrm{N}, 69^{\circ} 04.66^{\prime} \mathrm{W}$ & 192 & 35.5 \\
\hline
\end{tabular}

focus, and was estimated using the following laboratory calibration procedure. An acrylic target with a grid of $0.4 \mathrm{~mm}$ diameter holes was slowly moved through the depth of field as the VPR acquired images. The target was later isolated in the resulting images using AutoDeck with the same extraction parameters that were used for the in situ field data. The distance over which the target was in focus enough to be reliably extracted by AutoDeck is considered the depth of field. For the AutoVPR used in 2005, the depth of field was $75 \mathrm{~mm}$, and the resulting sample volume for each VPR image was $11 \mathrm{ml}$. For the DAVPR used in 2006 and 2007, the depth of field was $29.5 \mathrm{~mm}$, and the resulting sample volume was $2.1 \mathrm{ml}$. Taxon-specific abundance estimates were derived from the VPR using these estimates of the image volume and zooplankton counts from manually classified images. Comparable estimates of late-stage $C$. finmarchicus abundance were estimated from the OPC by counting 1.5 to $2.0 \mathrm{~mm}$ equivalent circular diameter particles and applying the calibration equation of Baumgartner (2003). The VPR malfunctioned on several occasions in 2006 because of slippage in the moveable bracket holding the camera in place, causing severe focus problems.

\section{RESULTS}

Fluorescence measurements were significantly correlated with chlorophyll concentration at the 2007 stations ( $\mathrm{n}=21, \mathrm{r}=0.744, \mathrm{p}<0.001$ ). There was no evidence that the intercept of the linear regression of fluorescence against chlorophyll concentration was different from zero $(t=0.46, \mathrm{p}=0.6504)$, so a fitted linear regression forced through the origin was used as a calibration equation to convert all fluorescence measurements to estimated chlorophyll concentrations. Qualitatively, migration patterns and copepod abundance estimates agreed very well between the OPC and VPR (see Figs. $3 \& 4$ ); hence, OPC observations were used to describe migration patterns and abundance, and VPR observations were used for individual prosome length and oil-sac volume estimates.

\section{Station 1}

Stn 1 was occupied 18 to 19 May 2005 for $27 \mathrm{~h}$ (Table 1). A persistent layer of late-stage Calanus finmarchicus was observed in the surface waters during both the daytime and nighttime (Fig. 3c,d). A second, much less abundant group of copepods appeared to migrate downward during the latter half of the first night, remain at depth during the day, and began an upward migration several hours before dusk. Fluorescence-derived chlorophyll concentration was moderate in the upper $30 \mathrm{~m}$, and the temporal variability in fluorescence suggested that phytoplankton were organized in patches that were advected past the station. The water column was weakly stratified in both temperature and salinity. Temporal variability in both temperature and salinity was dominated by tidal advection of cold salty (hence dense) water near the bottom (note doming of isopycnals near the sea floor in Fig. 3e), and variability in temperature near the surface was caused by daytime solar heating (not shown). Right and sei whales were present throughout the study period (Fig. 3a,b).

\section{Station 2}

Stn 2 was occupied 7 to 8 May 2006 for $21 \mathrm{~h}$ (Table 1), during which no coherent pattern in copepod vertical movements was observed. Copepods were organized in patches that remained at mid-depth during most of the study period, and these patches never occurred within $10 \mathrm{~m}$ of the surface. From images of individual copepods captured at depth by the VPR early in the study prior to the VPR malfunctioning, the population of Calanus finmarchicus appeared to be comprised of both CIV and CV copepodids (Table 2; length $<2.1 \mathrm{~mm}$ : $60 \%$, length $\geq 2.1 \mathrm{~mm}$ : $40 \%$ ). A concentrated patch of $C$. finmarchicus appeared near the sea floor during the morning of the second day coincident with the tidal advection of cold salty (hence dense) water near the sea floor (note doming of isopycnals near the sea floor in Fig. 3e). The lack of DVM and, in particular, the absence of copepods near the surface is likely explained by the distribution of phytoplankton (Fig. 3e). Fluorescence observations indicated that patches of phytoplankton were advected past the station at mid-depth (30 to $90 \mathrm{~m}$ ) and in phase with the tide, and that these patches occurred roughly in association with the $25.8 \mathrm{~kg} \mathrm{~m}^{-3}$ sigma-t isopycnal. As observed at Stn 1, stratification was quite weak, temporal variability in temperature and salinity was primarily caused by tidal advection, and daytime solar heating and nighttime cooling caused additional temporal variability in the surface temperatures (not 
之

Station 1
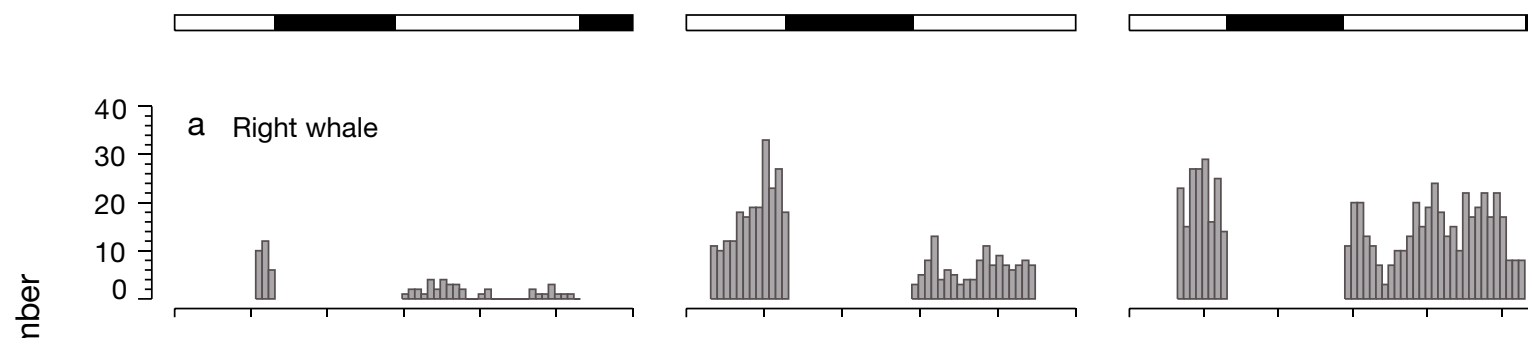

Station 2

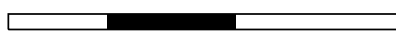

40 寻
30 寻
20 寻
0

b Sei whale
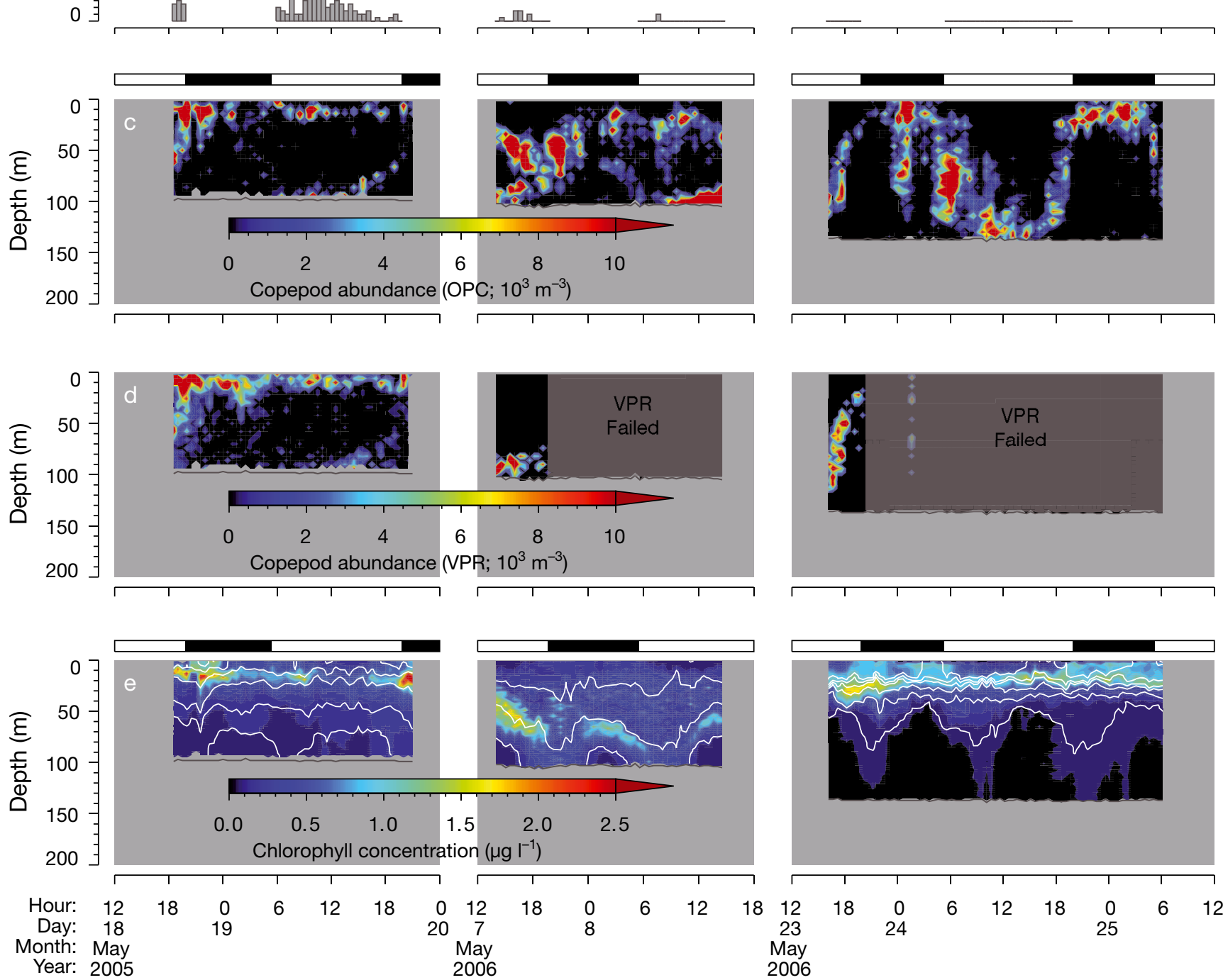

Fig. 3. Eubalaena glacialis, Balaenoptera borealis, and Calanus finmarchicus. Time series of (a) right whale abundance, (b) sei whale abundance, (c) optical plankton counter (OPC)-derived late-stage $C$. finmarchicus abundance, (d) video plankton recorder (VPR)-derived late-stage $C$. finmarchicus abundance, and (e) fluorometer-derived chlorophyll concentration at Stns 1 to 3 . Whale abundance expressed as the number of whales seen within $3 \mathrm{~km}$ of the ship during each 15 min daytime observation period. Each hour of visual effort in (a) and (b) is depicted as a vertical bar (number of whales $>0$ ) or horizontal line (number of whales $=0$ ). Isopycnals shown in (e) at $0.25 \mathrm{~kg} \mathrm{~m}^{-3}$ intervals (white lines). Bars at the top of (a), (c), and (e) indicate periods of daytime (white) and nighttime (black) 
shown). While right whale abundance was high (an average of 11.1 right whales were observed during each half-hourly observation period; Table 3), sei whale abundance was comparatively low (an average of 0.4 sei whales were observed; Table 3 ).

\section{Station 3}

Stn 3 was occupied from 23 to 25 May 2006 for $34.5 \mathrm{~h}$ (Table 1). Strong DVM was observed at this station and was characterized by high Calanus finmarchicus abundance near the surface at night and low abundance near the surface during the day (Fig. 3c). Copepods migrated to within $10 \mathrm{~m}$ of the sea floor during the daytime. VPR images taken early in the study prior to the VPR malfunctioning indicated that the migrators were comprised of both CIV and CV copepodids (Table 2; length $<2.1 \mathrm{~mm}$ : $45 \%$, length $\geq 2.1 \mathrm{~mm}$ : $55 \%$ ). Fluorescence-derived chlorophyll concentration was moderately high in the upper $30 \mathrm{~m}$, and phytoplankton was organized in discrete patches that advected past the station (Fig. 3e). The observed reduction in near- surface fluorescence during the daytime was probably not indicative of a reduction in phytoplankton, but was more likely caused by photoadaptation of phytoplankton cells to strong solar insolation. Unlike at Stns 1 and 2 , the water column was strongly stratified in both temperature and salinity (hence density), and phytoplankton patches occurred primarily in association with the pycnocline (Fig. 3e). Temporal variability in temperature and salinity was caused by tidal advection of salty low-fluorescence water near the bottom and cold water at mid-depth (Fig. 3e). Additional variability in temperature and salinity was caused by internal waves propagating past the station along the pycnocline (not shown). Right whale abundance was highest of all the stations (an average of 16.1 whales seen per observing period; Table 3), whereas no sei whales were observed at this station.

\section{Station 4}

Stn 4 was occupied from 21 to 23 May 2007 for $37.5 \mathrm{~h}$ (Table 1). Most copepods remained near the surface for

Table 2. Calanus finmarchicus. Morphometrics from images collected by the video plankton recorder (model DAVPR). Average and $95 \%$ CI of oil-sac volume derived from log-transformed statistics. Non-migrators = copepods that remained in the surface waters continuously

\begin{tabular}{|c|c|c|c|c|c|c|c|c|}
\hline \multirow{2}{*}{ Stn } & \multirow{2}{*}{$\begin{array}{l}\text { Behavioral } \\
\text { class }\end{array}$} & \multirow{2}{*}{$\mathrm{n}$} & \multirow[b]{2}{*}{$\begin{array}{l}\text { Mean } \\
(\mathrm{mm})\end{array}$} & \multirow[b]{2}{*}{$\begin{array}{c}95 \% \text { CI } \\
(\mathrm{mm})\end{array}$} & \multirow{2}{*}{$\begin{array}{c}\text { Length } \\
<2.1 \mathrm{~mm} \\
(\%)\end{array}$} & \multirow[b]{2}{*}{$\begin{array}{c}\geq 2.1 \mathrm{~mm} \\
(\%)\end{array}$} & \multicolumn{2}{|c|}{ Back-transformed oil-sac volume } \\
\hline & & & & & & & Average $\left(\mathrm{mm}^{3}\right)$ & $95 \% \mathrm{CI}\left(\mathrm{mm}^{3}\right)$ \\
\hline 2 & Non-migrators & 10 & 2.07 & $1.83-2.31$ & 60 & 40 & 0.0609 & $0.0431-0.0861$ \\
\hline 3 & Migrators & 33 & 2.20 & $2.12-2.28$ & 45 & 55 & 0.0661 & $0.0522-0.0838$ \\
\hline 4 & Non-migrators & 22 & 2.00 & $1.86-2.14$ & 68 & 32 & 0.0334 & $0.0239-0.0465$ \\
\hline 4 & Migrators & 31 & 2.26 & $2.15-2.37$ & 42 & 58 & 0.0640 & $0.0450-0.0909$ \\
\hline 5 & Non-migrators & 5 & 2.12 & $1.56-2.67$ & 40 & 60 & 0.0758 & $0.0393-0.1462$ \\
\hline 5 & Migrators & 45 & 2.39 & $2.31-2.47$ & 11 & 89 & 0.1083 & $0.0937-0.1252$ \\
\hline 5 & Deep & 9 & 2.43 & $2.32-2.54$ & 0 & 100 & 0.1440 & $0.1156-0.1794$ \\
\hline All & Non-migrators & 37 & 2.03 & $1.92-2.15$ & 62 & 38 & 0.0438 & $0.0344-0.055 \mathrm{c}$ \\
\hline All & Migrators & 109 & 2.30 & $2.24-2.35$ & 30 & 70 & 0.0803 & $0.0698-0.0924$ \\
\hline
\end{tabular}

Table 3. Calanus finmarchicus, Eubalaena glacialis, and Balaenoptera borealis. Summary of observations at each station. Average water column $C$. finmarchicus abundance, average daytime $C$. finmarchicus abundance at the surface $(<20 \mathrm{~m})$, and daytime percentage of $C$. finmarchicus at the surface $(<20 \mathrm{~m})$ were derived from optical plankton counter observations. Average whale abundance expressed as the number of whales per 15 min observation period. DVM: diel vertical migration

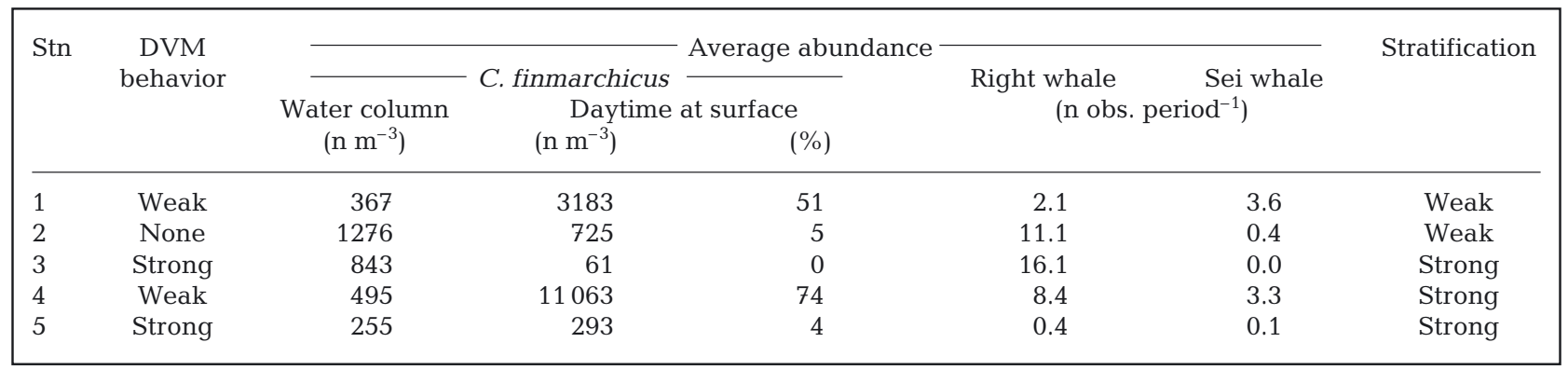


the duration of the observation period at this station (Fig. 4c,d), although a small segment of the population vertically migrated during the day (similar to that observed at Stn 1). The surface-resident non-migrating copepods imaged with the VPR were predominantly CIV copepodids (Table 2; length $<2.1 \mathrm{~mm}$ : $68 \%$ ), whereas the migrating segment of the population was comprised of both CIV and CV copepodids (Table 2; length $<2.1 \mathrm{~mm}: 42 \%$, length $\geq 2.1 \mathrm{~mm}: 58 \%$ ). The migrators had significantly larger prosome lengths (2-tailed $t$-test: $t=2.98, \mathrm{p}=0.0044)$ and oil-sac volumes (2-tailed $t$-test: $t=2.66, \mathrm{p}=0.0104$ ) than non-migrators. Chlorophyll concentration in the upper $25 \mathrm{~m}$ was moderately high. As at Stn 3, stratification was very strong, phytoplankton were associated with the pycnocline and the surface mixed layer, and daytime reductions in fluorescence likely caused by photoadaptation were observed (Fig. 4e). Daytime solar heating contributed to variability in surface temperature, but unlike at all the other stations, there was no temporal variability observed in temperature or salinity that could be attributed to tidal advection (note lack of tidal variability in isopycnals in Fig. 4e). This lack of variability suggests that horizontal gradients in temperature and salinity in the immediate vicinity of the station were quite small, whereas at all the other stations, horizontal gradients were larger. Both right and sei whales were present throughout the study period (Fig. 4a,b).

\section{Station 5}

Stn 5 was occupied from 6 to 8 June 2007 for $35.5 \mathrm{~h}$ in the northern Great South Channel (Table 1, Fig. 1). We observed strong DVM by the majority of copepods at this station (Fig. 4c,d), although there appeared to be 2 additional segments of the population that either remained in the surface waters during the day or remained at depth during the night. The copepods observed in the surface waters at the station during daylight hours were organized in a discrete patch that remained at the station for $4.5 \mathrm{~h}$. Because of the relatively low abundance of copepods in this daytime surface patch, only a few VPR images were of sufficient quality to obtain prosome length and oil-sac volume $(\mathrm{n}=5)_{\text {; }}$ these measurements suggested the patch was comprised of both CIV and CV copepodids (Table 2; length $<2.1 \mathrm{~mm}: 40 \%$, length $\geq 2.1 \mathrm{~mm}: 60 \%$ ) with small oil sacs (back-transformed average volume: $0.0758 \mathrm{~mm}^{3}$ ). The layer of copepods around $165 \mathrm{~m}$ depth was much more persistent than the daytime surface patch, remaining observable for the entire duration of the station. The prosome length data suggested that this layer was dominated by $\mathrm{CV}$ copepodids (Table 2; fraction $\geq 2.1 \mathrm{~mm}$ : $100 \%$ ) with oil sacs nearly twice the size of those measured in the daytime surface patch (Table 2; back-transformed average volume: $0.144 \mathrm{~mm}^{3}$ ). Despite the low sample sizes, the oil-sac volumes for copepods in the daytime, non-migrating, surface patch and in the deep persistent layer were significantly different (2-tailed $t$-test: $t=2.99, \mathrm{p}=$ 0.0112 ). The migrating layer was also dominated by CV copepodids (Table 2; length $\geq 2.1 \mathrm{~mm}$ : $89 \%$ ) that had lengths similar to those observed in the persistent deep layer (2-tailed $t$-test: $t=0.42, \mathrm{p}=0.6766)$; however, there was suggestive, but inconclusive, evidence that copepods in the migrating layer had smaller oil sacs than those in the persistent deep layer (2-tailed $t$-test: $t=1.70, \mathrm{p}=0.0947$; note that because $\mathrm{n}_{\text {deep }}=9$, this test is not particularly powerful).

Fluorescence-derived chlorophyll concentration was highest of any of the stations, and phytoplankton were concentrated primarily in the pycnocline and in the surface mixed layer (Fig. 4e). The water column was strongly stratified in temperature, but less so in salinity (Fig. 5). Temporal variability in temperature and salinity was caused by tidal advection of cold fresh water at mid-depth and warm salty water near the bottom (note doming of isopycnals in Fig. 4e). Additional variability in temperature and salinity was caused by internal waves propagating past the station at the pycnocline (not shown). Warm, salty, and turbid conditions near the bottom (Fig. 5) indicated the presence of water originating from the continental slope that was absent at all other stations (likely due to the proximity of Stn 5 to slope-origin water at the bottom of Wilkinson Basin; Fig. 1). The abundance of Calanus finmarchicus was comparatively low in this water mass, particularly in the bottom mixed layer (Fig. 5). Right and sei whales were observed only occasionally at this station (Fig. 4a,b), likely because the overall copepod abundance was lowest of all the stations (Table 3).

\section{DVM behavior and hydrographic conditions}

A range of hydrographic conditions was observed throughout the 3 yr study, from weak stratification and relatively cooler surface temperatures (Stns 1 and 2) to strong stratification and warmer surface temperatures (Stns 3, 4, and 5). Advection of different water masses in phase with the tide was observed at all stations except for Stn 4. Despite this broad range of conditions (Table 3), no relationship was apparent between the DVM behavior of late-stage Calanus finmarchicus and these hydrographic conditions or variability. Both strong and weak DVM behavior was observed during periods of strong stratification (e.g. Stns 4 and 5), and limited vertical migration behavior was observed during weak stratification (Stn 1). 
Station 4
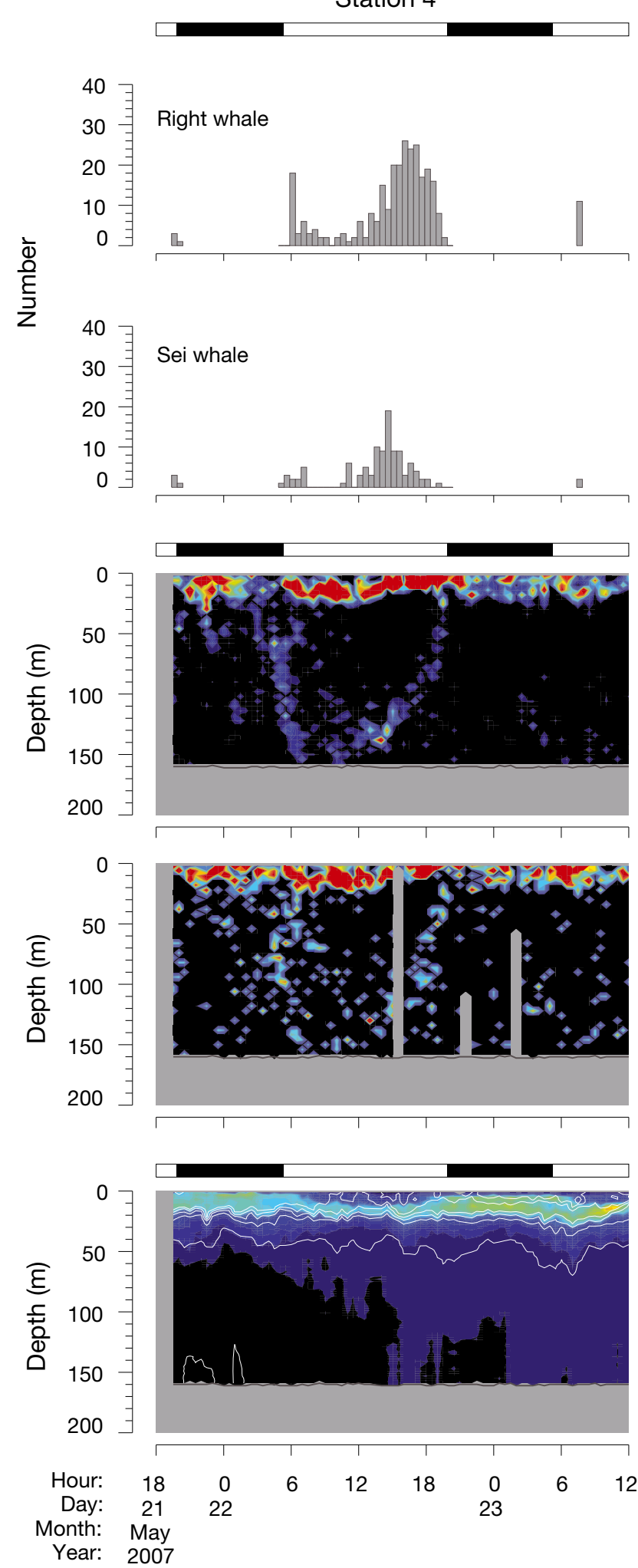

Station 5
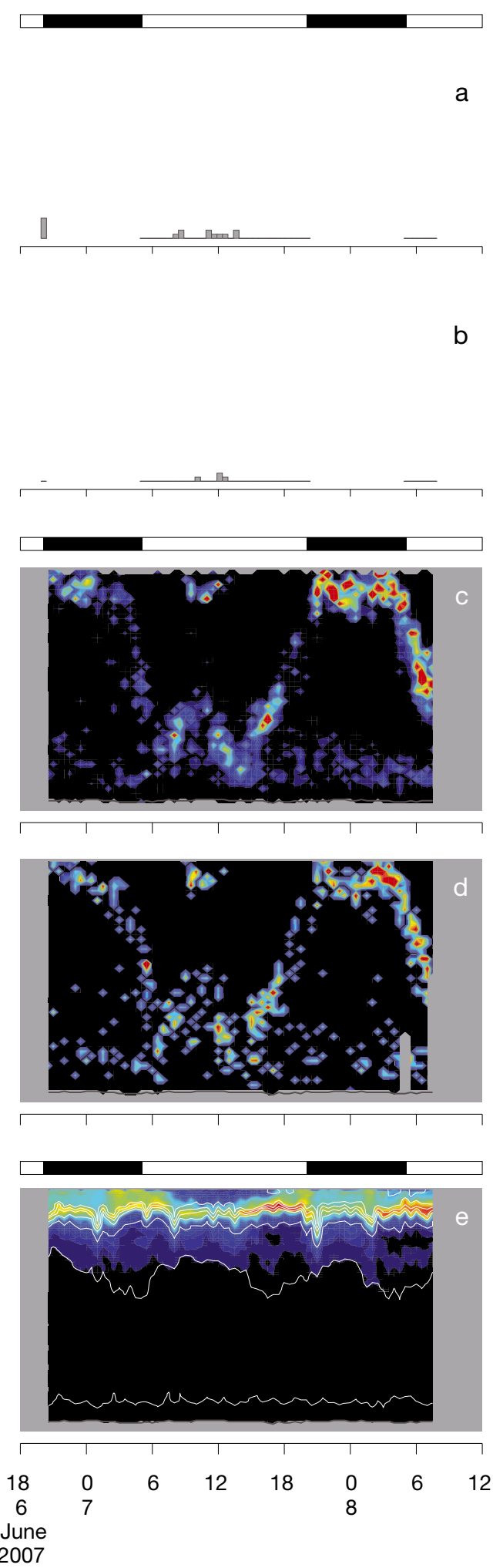

Fig. 4. Eubalaena glacialis, Balaenoptera borealis, and Calanus finmarchicus. Time series of (a) right whale abundance, (b) sei whale abundance, (c) optical plankton counter-derived late-stage $C$. finmarchicus abundance, (d) video plankton recorderderived late-stage $C$. finmarchicus abundance, and (e) fluorometer-derived chlorophyll concentration at Stns 4 and 5. In all other respects, the figure is identical to Fig. 3 


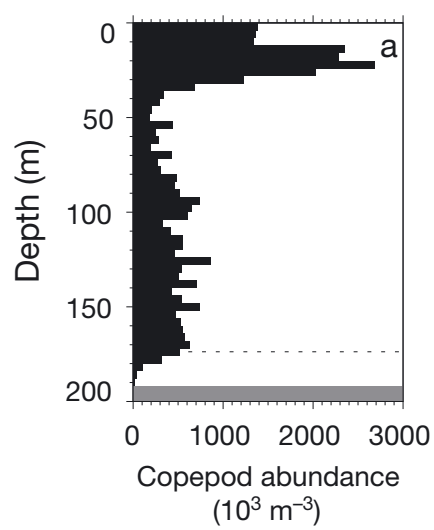

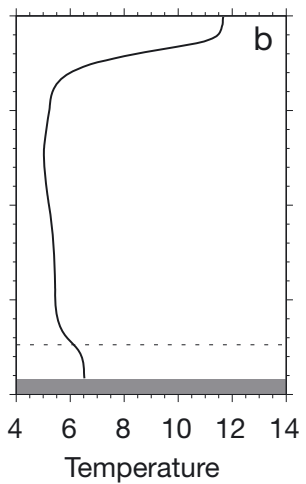

$\left({ }^{\circ} \mathrm{C}\right)$

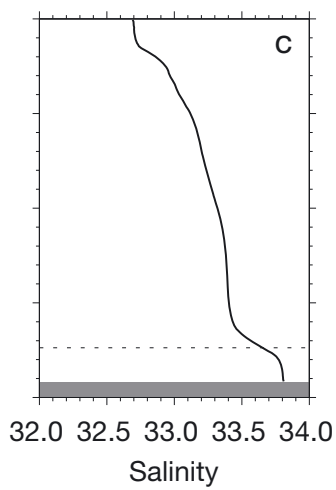

Salinity

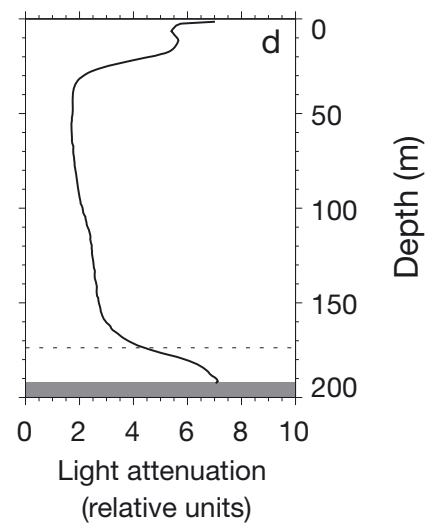

Fig. 5. Calanus finmarchicus. Profiles of (a) optical plankton counter-derived late-stage C. finmarchicus abundance, (b) temperature, (c) salinity, and (d) light attenuation averaged over all casts at Stn 5 ( $\mathrm{n}=71$ casts). Shaded region at bottom depicts the sea floor and the dotted line indicates the top of the bottom mixed layer (defined as the deepest depth at which the density differed from the bottom density by at least $0.05 \mathrm{~kg} \mathrm{~m}^{-3}$ )

\section{DVM behavior and phytoplankton distribution}

Although DVM behavior was not directly linked with stratification, the vertical distribution of phytoplankton appeared to be controlled in large part by stratification. During highly stratified periods (Stns 3 to 5), phytoplankton layers were observed in the pycnocline, presumably between the nutrient-depleted, well-lit surface waters and the deep nutrient reservoir below the pycnocline. When stratification was particularly weak (Stn 2), phytoplankton occurred at depth. The depth distribution of Calanus finmarchicus was closely associated with the depths at which their food occurred; we observed that (1) during periods of strong DVM (Stns 3 and 5), C. finmarchicus migrated at night to the pycnocline where phytoplankton abundance was highest, (2) during periods of weak DVM (Stns 1 and 4), most $C$. finmarchicus remained continuously near the surface where phytoplankton abundance was highest, and (3) during periods of non-migration behavior (Stn 2), C. finmarchicus remained at mid-depth where phytoplankton abundance was highest.

\section{DVM behavior, copepod stage distribution, and oil-sac size}

Prosome lengths derived from all images of Calanus finmarchicus obtained by the DAVPR in 2006 and 2007 (Stns 2 to 5) suggested that both non-migrating and migrating copepods were in stages CIV and CV; however, surface-resident non-migrating copepods were primarily in stage CIV (Table 2; length $<2.1 \mathrm{~mm}$ : $62 \%$ ), and migrating copepods were primarily in stage $\mathrm{CV}$ (Table 2 ; length $\geq 2.1 \mathrm{~mm}: 70 \%$ ). As a result, migrating copepods were significantly longer than non-migrating copepods (Fig. 6a; 2-tailed t-test: $t=4.67, \mathrm{p}<$
0.001). Migrating copepods also had significantly larger oil sacs than surface-resident non-migrating copepods (Fig. 6b; 2-tailed $t$-test: $t=4.32$, $\mathrm{p}<0.001$ ), which could similarly result from differences in the stage distribution between the 2 groups since CIV copepodids generally have much smaller oil sacs than CV copepodids. To account for the effect of stage distribution on the observed oil-sac volumes, the following multiple linear regression model was fit with prosome length as a nuisance variable: $\ln (V)=\beta_{0}+\beta_{1} L+$ $\beta_{2} M$, where $V$ is the oil-sac volume, $L$ is the prosome length, $M$ is an indicator variable set to 0 for surfaceresident non-migrating copepods and set to 1 for migrating copepods, and $\beta_{0}, \beta_{1}$, and $\beta_{2}$ are the model parameters. Thus, for copepods of similar length (i.e. of the same stage), $e^{\beta_{2}}$ indicates the multiplicative difference in the median oil-sac volume between migrating and non-migrating copepods. For Stns 2 to 5 combined, the median oil-sac volume of migrating copepods was $31.5 \%(95 \% \mathrm{CI}: 1.71$ to $70.1 \%)$ larger than that of surface-resident non-migrating copepods after accounting for prosome length in this way $\left(\mathrm{n}_{\text {migrators }}=109\right.$, $\mathrm{n}_{\text {non-migrators }}=37 ; \beta_{2}=0.2742 ; 95 \%$ CI: 0.01691 to $0.5314 ; 1$-tailed $\mathrm{p}=0.0184$; a 1 -tailed test is used here since the alternative to the null hypothesis, H1, states that migrating copepods have larger oil sacs than nonmigrating copepods). A second multiple linear regression model was fit with stage explicitly included as a nuisance variable, where stage was classified by prosome length (i.e. length $<2.1 \mathrm{~mm}$ was classified as CIV, and length $\geq 2.1 \mathrm{~mm}$ was classified as $C V)$ : $\ln (V)=\beta_{0}+$ $\beta_{1} S+\beta_{2} M$, where $S$ is an indicator variable set to 0 for $\mathrm{CIV}$ and set to 1 for CV. The median oil-sac volume of migrating copepods was $43.8 \% \quad$ (95\% CI: 11.5 to $85.3 \%$ ) larger than that of surface-resident nonmigrating copepods after accounting for stage in this way $\left(\mathrm{n}_{\text {migrators }}=109, \mathrm{n}_{\text {non-migrators }}=37 ; \beta_{2}=0.3631 ; 95 \%\right.$ 

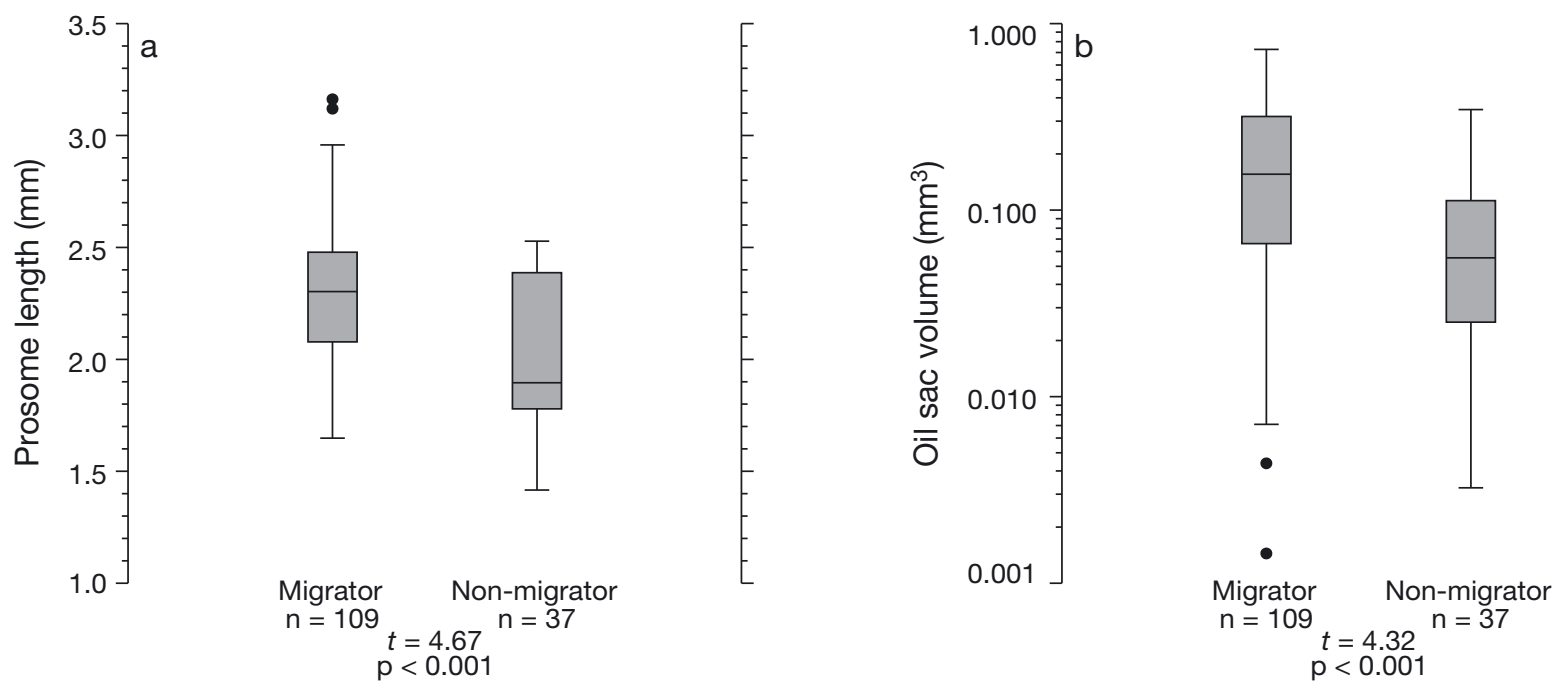

Fig. 6. Calanus finmarchicus. (a) Prosome length and (b) oil-sac volume of migrating and surface-resident non-migrating C. finmarchicus imaged with the video plankton recorder (model DAVPR) for Stns 2 to 5

CI: 0.1093 to $0.6169 ; 1$-tailed $\mathrm{p}=0.0027$; again, $\mathrm{a}$ 1 -tailed test is used here since the alternative to the null hypothesis, H1, states that migrating copepods have larger oil sacs than non-migrating copepods).

\section{DVM behavior and predator occurrence}

No systematic observations of major Calanus finmarchicus predators were collected during any of the stations (see 'Discussion' as to why right and sei whales are not considered major $C$. finmarchicus predators). However, an aggregation of sand lance (Ammodytes spp.) was serendipitously observed at the surface during the first night at Stn 5. Fish were extremely abundant and could be easily caught with a 5 gallon (19 l) bucket. An examination of stomach contents indicated that the fish were feeding on latestage C. finmarchicus. Sand lance were first observed on 7 June 2007 at 01:00 h local time and persisted at the station for $3.5 \mathrm{~h}$. It is likely that the aggregation was fairly large, since it remained at the station for several hours despite relatively strong currents associated with the ebb tide (although it is possible that the aggregation was small and actively swam to remain close to the ship). We suspect that the sand lance near the vessel were able to feed on C. finmarchicus using the ship's lights, but since sand lance are visual predators, the majority of fish comprising the aggregation (i.e. those fish that were not near the ship) were not able to feed on C. finmarchicus near the surface at night. The presence of a large aggregation of predators may have influenced the DVM behavior of $C$. finmarchicus at this station.

\section{Variability in whale abundance}

Whale abundance varied both within and among stations (Figs. 3a,b \& 4a,b, Table 3). Although the abundance of whales varied within each station period (Figs. 3a,b \& 4a,b), there was no relationship between the within-station average water column abundance of Calanus finmarchicus and the abundance of either right or sei whales. Similarly, there was no relationship between maximum water-column abundance of $C$. finmarchicus and the abundance of either right or sei whales within each station period. In other words, we did not tend to detect more whales within $3 \mathrm{~km}$ of the station when the concentration of $C$. finmarchicus was higher over the course of a single station. There was also little evidence that the within-station variability in whale abundance was caused by tidal advection of whales past the station. There was only 1 instance of tidal periodicity in the time series of whale abundance: at Stn 4 on 22 May 2007, both right and sei whale abundance reached a local minimum around slack tide between the ebb and flood tides (Fig. 4a,b; tides not shown in figure). The variability in abundance on this day may have been caused by a very discrete aggregation of whales distributed over a relatively small area (a few kilometers) that could be observed passing the station. At the other stations, whales were more likely distributed over a wider area (several to tens of kilometers); hence, their movements past the station caused by the tide would be much less observable.

Average whale abundance varied substantially among stations (Table 3). Right whale abundance averaged over each station varied from 0.4 to 16.1 whales seen per 15 min observation period, while average sei whale abundance varied from 0.0 to 3.6 whales. Right 
whale abundance tended to be higher when the average water-column abundance of Calanus finmarchicus was higher $(n=5, r=0.756, p=0.14)$, and although this result was not statistically significant, the power of this test is quite low. No relationship was observed between sei whale abundance and the average watercolumn abundance of $C$. finmarchicus $(\mathrm{n}=5, \mathrm{r}=$ $-0.443, p=0.45)$. Variability in right whale abundance was unrelated either to daytime, surface, $C$. finmarchicus abundance ( $\mathrm{n}=5, \mathrm{r}=-0.0694, \mathrm{p}=0.91$ ) or to the daytime percentage of $C$. finmarchicus at the surface $(\mathrm{n}=5, \mathrm{r}=-0.274, \mathrm{p}=0.66), 2$ measures of DVM behavior (surface waters defined as those above $20 \mathrm{~m}$ depth). In contrast, sei whale abundance tended to be higher during periods of weak DVM when daytime concentrations of C. finmarchicus at the surface were high $(\mathrm{n}=5, \mathrm{r}=0.753, \mathrm{p}=0.14$; result not statistically significant, but the power of this test is low) and the daytime percentage of $C$. finmarchicus at the surface was high $(\mathrm{n}=5, \mathrm{r}=0.950, \mathrm{p}=0.013)$. These results suggest that right whale occurrence is unaffected by $C$. finmarchicus DVM behavior, whereas sei whales are less abundant during times of strong DVM (hypothesis H2).

\section{DISCUSSION}

We observed considerable variability in DVM behavior, including strong migration behavior (Stns 3 and 5), weak migration behavior (Stns 1 and 4), and no migration behavior (Stn 2). Hydrographic conditions did not appear to have a significant effect on this variability. Migration was observed in both weakly and strongly stratified conditions, with and without internal wave activity (i.e. during periods of strong and weak stratification, respectively), and with and without strong tidal variability in hydrographic properties. However, it is possible that stratification has an indirect influence on DVM behavior, as a strong pycnocline can promote the formation of a discrete subsurface maximum in phytoplankton abundance that, in turn, will attract copepods toward the surface.

\section{Why migrate up?}

Our observations strongly support the hypothesis that upward migration is motivated by the availability of phytoplankton in the surface waters. During DVM (strong or weak), phytoplankton concentrations were always highest in the upper $30 \mathrm{~m}$, and there was no evidence of active (fluorescent) phytoplankton cells occurring in abundance below the pycnocline. However, when phytoplankton were not concentrated at the surface but instead at depth during the weakly stratified conditions at Stn 2, copepods did not migrate to the surface. These observations indicate that DVM behavior is by no means fixed, but instead is responsive to local phytoplankton distribution (Ohman 1990). The early summer observations of Ohman \& Runge (1994) demonstrated that Calanus finmarchicus is omnivorous and can feed on heterotrophic microplankton. During our springtime study, the close association between C. finmarchicus vertical distribution and that of phytoplankton strongly suggests that C. finmarchicus feeds primarily on phytoplankton at this time of year in the southwestern Gulf of Maine.

\section{Why migrate down?}

Despite the strong dependence on phytoplankton availability in the near-surface waters for upward migration behavior, there was no evidence to suggest that downward migration was related to phytoplankton distribution or abundance. Copepods clearly did not leave the surface waters just prior to dawn because phytoplankton distribution changed or phytoplankton became less abundant (Figs. $3 \mathrm{e} \& 4 \mathrm{e}_{\text {; }}$ recall that apparent near-surface daytime reductions in chlorophyll concentration are most likely an artifact of measuring fluorescence during periods of photoadaptation to strong sunlight). Similarly, there were no obvious changes in hydrographic conditions that appeared to prompt downward migration. Our anecdotal observation of sand lance at Stn 5 when strong DVM behavior was also observed suggests that the presence of visual predators may be the ultimate cause of downward migration. This conclusion is consistent with many experiments and field studies that have demonstrated that downward vertical migration by zooplankton is caused by the occurrence of predators (e.g. Zaret \& Suffern 1976, Gliwicz 1986, Bollens \& Frost 1989, Dawidowicz et al. 1990, Bollens et al. 1992).

\section{Why stay in surface waters during daytime?}

During surveys at Stns 1 and 4, most Calanus finmarchicus remained at the surface throughout both the day and night. Interestingly, at each of these stations, a smaller segment of the population chose to vertically migrate despite being exposed to identical environmental conditions as the non-migrating copepods. The reasons for remaining at the surface during the daytime are not immediately clear, but it is possible that either (1) no visual predators were present, or (2) visual predators were present, but copepods risked predation to remain at the surface to feed. While we made no systematic observations of visual predator 
occurrence, the fact that part of the population chose to vertically migrate suggests that visual predators might have been present at these stations. If predators were indeed present, why would the majority of the population remain at the surface? Phytoplankton are not always available in sufficient concentrations to sate a copepod, and food limitation of growth and maturation has been observed for C. finmarchicus in the Gulf of Maine (Campbell et al. 2001b). During conditions of low food availability, or during blooms that follow periods of low food availability, copepods may risk predation and continue to feed at the surface during the daytime to either prevent starvation or to build lipid reserves quickly. Since substantial ingested energy is accumulated in the oil sac during CIV and CV stages, the size of this oil sac or, equivalently, the store of lipids can be used as an indicator of past feeding success (Graeve et al. 2005). We might expect, then, that recently food-limited copepods with small oil sacs will tend to remain at the surface during the day to feed, whereas recently well-fed copepods with larger oil sacs will vertically migrate. The morphometric analysis of the VPR images supports this hypothesis; we found that the oil sacs of migrating copepods were $44 \%$ larger than those of surface-resident non-migrating copepods after accounting for developmental stage.

Durbin et al. (1995b) suggest that Calanus finmarchicus in the Great South Channel are likely foodlimited after the spring bloom terminates and stratification is established. Using a chlorophyll concentration of $1 \mathrm{\mu g} \mathrm{l}^{-1}$ as an approximate threshold for food limitation of $C$. finmarchicus (Campbell et al. $2001 \mathrm{~b}$ ), we found that all of the stations had patches of phytoplankton that exceeded this threshold, although only Stns 3 to 5 had persistent chlorophyll concentrations in excess of $1 \mu \mathrm{g} \mathrm{l}^{-1}$. This phytoplankton patchiness may be responsible for differences in oil-sac size among individual copepods. When copepods ascend from depth at dusk, some arrive at the surface inside a phytoplankton patch and can feed at maximal rates, whereas others will arrive to considerably lower phytoplankton abundance and possibly food-limiting conditions. This differential rate of ingestion and lipid deposition will result in some copepods 'fattening up' sooner than others, and may result in the weak DVM observed at Stns 1 and 4 where only copepods with larger oil sacs initiate DVM and the rest of the population must remain at the surface to feed during the daytime.

\section{Why stay at depth?}

We observed a persistent layer of primarily CV copepodids at depth during Stn 5 that did not migrate. Our initial assumption was that this was a diapausing layer of Calanus finmarchicus, since it remained at depth and was composed mostly of CV copepodids, 2 of the several qualitative characteristics of diapausing populations (Hirche 1996). However, our estimates of oil-sac size, albeit few ( $n=9$ ), suggested the copepods in this persistent layer had much smaller oil sacs than previously sampled copepods in this area. Tarrant et al. (2008) sampled CV copepodids both at the surface (0 to $39 \mathrm{~m}$ ) and at depth (157 to $201 \mathrm{~m}$ ) $68 \mathrm{~km}$ to the east of Stn 5 during 2005. Compared to the surface-collected copepods, the deep copepods had significantly larger oil sacs, lower RNA:DNA ratios (an indication of reduced transcriptional activity), and empty guts. These presumably diapausing copepods collected in 2005 had oil sacs that were $175 \%$ larger than the oil sacs of the copepods comprising the deep persistent layer at Stn 5 (2005 data: mean \pm SD oil-sac size $=0.3967 \pm$ $0.0755 \mathrm{~mm}^{3}, \mathrm{n}=25$; data from Tarrant et al. 2008). It is therefore unlikely that the deep copepods at Stn 5 were in diapause. Why, then, did these copepods stay at depth?

Durbin et al. (1995a,b) also observed deep, nondiapausing, non-migrating Calanus finmarchicus in the Great South Channel that were larger and less pigmented than collocated surface copepods. Fluorescence profiles and Niskin bottle samples from the water column indicated that there was a layer of phytoplankton up to $30 \mathrm{~m}$ thick near the bottom, and gut fluorescence measurements indicated that the deep copepods were actively feeding. Durbin et al. (1995a,b) concluded that these copepods were feeding on diatoms from the spring bloom that had recently settled out of the water column onto the sea floor. Presumably these copepods had no need to visit the surface waters with phytoplankton available at depth. In the present study, however, we found no increase in fluorescence at depth that would suggest a phytoplankton food source for the deep non-migrating C. finmarchicus at Stn 5 (Fig. 4e). We did find similar conditions to those reported by Durbin et al. (1995a,b) at Stn 2, where C. finmarchicus was found coincident with deep layers of concentrated phytoplankton (Fig. 3). We did not assess phytoplankton community composition or copepod ingestion rates, but based on the co-occurrence of the copepods and phytoplankton, previous studies reporting copepods feeding on phytoplankton at depth (Durbin et al. 1995a,b, Dagg et al. 1997), and the time of year (early in May during the waning spring bloom; Thomas et al. 2003), it is likely that $C$. finmarchicus at Stn 2 were feeding on algal cells (possibly spring bloom diatoms) that were sinking in the water column.

Hays et al. (2001) observed deep non-migrating Metridia pacifica in Dabob Bay, a fjord in Washington 
state (USA), coincident with migrating $M$. pacifica, and they reported that the deep non-migrating copepods had oil sacs that were $72 \%$ larger than those of migrating copepods. From these observations, Hays et al. (2001) concluded that the deep non-migrating copepods had sufficient energy reserves to forgo migration to the surface, hence avoiding the risk of predation. Moreover, Hays et al. (2001) estimated that M. pacifica could survive for 3 to $9 \mathrm{~d}$ at depth before having to return to the surface to feed. At Stn 5, we observed a similar pattern to that of Hays et al. (2001); copepods in the deep layer had oil-sac volumes $33 \%$ larger than migrating copepods, and $90 \%$ larger than the non-migrating copepods that remained at the surface throughout the daytime. It is possible that these copepods had sufficient energy reserves to forgo migration; however, unlike M. pacifica (Batchelder 1985), it is thought that Calanus finmarchicus builds energy reserves primarily in preparation for diapause, not to survive relatively short periods of starvation at depth. Although it seems avoiding predation by remaining at depth and metabolizing lipid reserves may be a reasonable short-term strategy for survival, it may not always be compatible with the long-term goal of building sufficient lipid reserves to enter diapause. In truth, short-term utilization of energy reserves is not well studied in C. finmarchicus; thus, while Hays et al. (2001) speculated that $M$. pacifica with large lipid reserves mitigated predation by remaining at depth for short periods of time (days), it is unclear if C. finmarchicus employs a similar strategy in the Gulf of Maine.

\section{Seasonal variability in DVM behavior}

From the stations occupied within the same year, it is clear that DVM behavior changes within the same season. Although there was only a single station in 2005, the glider study of Baumgartner \& Fratantoni (2008) took place $25 \mathrm{~km}$ to the northwest and over the course of 7 to $12 \mathrm{~d}$ prior to Stn 1 . Baumgartner \& Fratantoni (2008) observed strong DVM, whereas only weak vertical migration was observed at Stn 1. In 2006, no DVM behavior was observed in early May (Stn 2), whereas strong DVM was observed later that month at a location only $14.5 \mathrm{~km}$ away (Stn 3). Significant differences in migration behavior were also observed between the 2 stations occupied in 2007; however, these stations were $70 \mathrm{~km}$ apart. In each year, roughly 2 wk elapsed between sampling periods; therefore, we are unable to estimate how quickly DVM behavior changes. The glider observations of Baumgartner \& Fratantoni (2008) indicate that strong vertical migration behavior persisted for several days, and strong vertical migration behavior occurred at least $2 \mathrm{~d}$ in a row at Stns 3 and 5.

\section{Influence of zooplanktivorous whales on DVM behavior}

Right and sei whales are most likely inconsequential predators of Calanus finmarchicus, and therefore have no influence on DVM behavior. Despite the astounding amount of $C$. finmarchicus consumed daily by individual whales (estimated at 1 to 2 billion copepods; Kenney et al. 1986, Baumgartner \& Mate 2003), there simply are not enough whales in the population for them to be considered major predators of $C$. finmarchicus. Baumgartner et al. (2003a) compared right whale consumption of C. finmarchicus in the lower Bay of Fundy to that of a single invertebrate predator of $C$. finmarchicus, the northern krill Meganyctiphanes norvegica, and conservatively estimated that the krill consume 7.5 times more $C$. finmarchicus than the right whales. Northern krill are only one of many extremely abundant predators of C. finmarchicus, and this comparison was done in an area where right whales are highly aggregated. The actual contribution of right whales to the overall predation of $C$. finmarchicus in the Gulf of Maine is therefore assumed to be negligible. Since an individual copepod is far more likely to be consumed by other predators, it seems doubtful that they would evolve behavioral strategies to avoid predation by right and sei whales.

\section{Influence of DVM behavior on zooplanktivorous whales}

The difference in the response of right whales and sei whales to variability in the DVM behavior of Calanus finmarchicus was striking. Whereas right whale abundance remained high during periods of strong, weak, and no DVM behavior, sei whales occurred in much lower numbers or were absent altogether when C. finmarchicus did not occupy the surface waters during the daytime (e.g. during periods of strong DVM behavior). The high abundance of right whales observed during times when copepods were at depth during the day strongly suggests that right whales are capable of feeding well below the surface waters. Winn et al. (1995) inferred that right whales roughly tracked the day/night movements of $C$. finmarchicus in the Great South Channel by monitoring dive times using radio tags; they observed longer dive times during the day than during the night while copepods were vertically migrating, and suggested that right whales were feeding on the copepods at depth during the day and at the surface at night. Short-term tagging studies in the right whales' summertime habitat, the lower Bay of Fundy, indicate that right whales are adept at feeding at depths of 150 to $200 \mathrm{~m}$ on dis- 
crete layers of $C$. finmarchicus (Baumgartner \& Mate 2003). Using short-term tagging methods identical to those employed by Baumgartner \& Mate (2003), we have observed right whales foraging at the sea floor during the daytime in the Great South Channel (M. F. Baumgartner unpubl.). However, surface feeding is likely less energetically expensive for right whales than feeding at depth because transit time to the depth of a prey layer is reduced, thus time spent feeding inside the layer is increased for a constant dive time (Baumgartner et al. 2003b). Our observations suggest that right whales may sometimes have a choice of depths at which to forage (e.g. Stns 1, 4, and 5). Since migrating $C$. finmarchicus had oil sacs that were $44 \%$ larger than surface-resident non-migrating copepods (regardless of developmental stage), the costs of feeding at depth during the day may sometimes be outweighed by the benefit of feeding on larger lipid-rich copepods with a higher caloric content. Alternatively, right whales could concentrate their feeding activities at the surface at night when both non-migrating and migrating copepods are available together in a single, easily accessible layer.

In contrast to right whales, the absence of sei whales during times when copepods were at depth suggests that sei whales may only be able to feed effectively on Calanus finmarchicus when they are at or near the surface. Baumgartner \& Fratantoni (2008) observed diel variability in sei whale calling rates in association with acoustic observations of strong C. finmarchicus DVM behavior in the Great South Channel during the spring; specifically, they observed low calling rates during the night when $C$. finmarchicus were at the surface, and higher calling rates during the day when C. finmarchicus were at depth. They speculated that sei whales reduced calling rates to accommodate nighttime feeding on $C$. finmarchicus at the surface, and increased calling rates during the day when prey was unavailable to them. If sei whales were as adept at feeding at the surface during the night as during the day, then we might expect them to be present during periods of strong DVM. However, the present study indicates that sei whales are generally absent during these times (e.g. Stns 3 and 5). These observations together suggest that sei whales may prefer to feed on C. finmarchicus at the surface during the day. Baumgartner \& Fratantoni (2008) discussed a number of hypotheses for sei whales' apparent reliance on nearsurface copepod patches, including the lack of a subrostral gap in their baleen, inferior sensory capabilities for detecting copepods, and an ability to switch to other prey that may be more easily captured when near-surface patches are not available.

Despite strong DVM observed in the Great South Channel during 2005 by Baumgartner \& Fratantoni
(2008), during 2006 at Stn 3, and during 2007 at Stn 5, sei whale downsweep calls were detected during concurrent acoustic monitoring at each of these study sites (Baumgartner \& Fratantoni 2008, Baumgartner et al. 2008), indicating that sei whales remained in the region despite a lack of daytime surface aggregations. If sei whales can only feed on daytime surface aggregations, why would they remain in the area when these aggregations are not available? Although sei whales are capable of switching to prey other than Calanus finmarchicus (Hjort \& Ruud 1929, Kawamura 1974, Flinn et al. 2002), we speculate that the withinseason variability in DVM behavior described above (see 'Seasonal variability in DVM behavior') may offer an alternative explanation. During 2005, Baumgartner \& Fratantoni (2008) observed strong DVM by C. finmarchicus, but just over a week later, we observed weak DVM at Stn 1. It is possible that sei whales wait in the Great South Channel until DVM behavior ends and $C$. finmarchicus become available again in daytime surface aggregations. Given the patchiness of forage fish, it is also conceivable that there is spatial variability in DVM behavior, and sei whales can find and forage on daytime surface aggregations while elsewhere in the Great South Channel copepods are exhibiting strong DVM behavior. Addressing these alternatives requires monitoring the diving and foraging behavior of individual sei whales.

\section{Competition}

In 1986, Payne et al. (1990) observed an anomalous reduction in sand-lance abundance on Stellwagen Bank in the western Gulf of Maine and an equally anomalous increase in both right whale and sei whale abundance. Coincident with this reduction in sand lance, they reported that Calanus finmarchicus abundance in 1986 was an order of magnitude higher than in any other year of their study from 1982 to 1988. They reasoned that right whales compete for copepods with zooplanktivorous fish that also feed on $C$. finmarchicus (e.g. herring, mackerel, and sand lance), and that the abundance of these fish can influence the occurrence of right and sei whales by controlling the abundance of C. finmarchicus available to the whales. From the results of their regional study, Payne et al. (1990) suggested that the recovery of the endangered North Atlantic right whale may be inhibited in the northwest Atlantic Ocean by competition for its prey by zooplankivorous fish.

Our results suggest that the interactions among right whales, sei whales, and zooplanktivorous fish may be more complicated than originally envisioned by Payne et al. (1990). In particular, we speculate that the behav- 
ior of Calanus finmarchicus likely has a strong influence on these interactions. The Payne et al. (1990) study was conducted in relatively shallow waters (18 to $40 \mathrm{~m}$ depth) where $C$. finmarchicus probably cannot migrate to sufficient depths to avoid predation by visual predators (C. finmarchicus migrated to well below $40 \mathrm{~m}$ in our study; Figs. 3c \& 4c); therefore, zooplanktivorous fish may have a much greater influence on the abundance of $C$. finmarchicus over banks (e.g. Stellwagen Bank) than they do in deeper habitats. In the Great South Channel, where a deep-water dark refuge is available, DVM behavior may allow C. finmarchicus to avoid predation such that fish will have much less of an effect on copepod abundance. This behavior will reduce the extent to which zooplanktivorous fish compete with right whales, since right whales can take advantage of migrating copepods at depth during the day (Baumgartner \& Mate 2003) and presumably at the surface at night, i.e. at times when these same copepods are unavailable to fish that rely on visual hunting. In contrast, zooplanktivorous fish and sei whales may compete more directly, and the presence of fish could affect sei whales in 2 ways: (1) by inducing DVM behavior, zooplanktivorous fish may inadvertently preclude sei whales from foraging since sei whales appear restricted to feeding on copepods near the surface and perhaps only during the daytime, and (2) by competing directly for persistent near-surface daytime aggregations of $C$. finmarchicus that have not initiated DVM (e.g. Stns 1 and 4).

Stocks of herring in the Gulf of Maine have recently recovered from overfishing (Overholtz \& Friedland 2002), and concern has been expressed about potential competition between these fish and right whales for Calanus finmarchicus. Greene \& Pershing (2004) found that annual right whale calf production is likely related to Calanus finmarchicus abundance such that fewer calves are born after years of low Calanus finmarchicus abundance. An increase in herring may therefore reduce the abundance of late-stage Calanus finmarchicus available to fuel right whale productivity. As discussed in the previous paragraph, we speculate that right whales and herring do not compete directly in deep-water habitats during the spring (Great South Channel), since Calanus finmarchicus likely initiates DVM behavior to avoid predation by the far more abundant fish predator. In summertime habitats (lower Bay of Fundy and southwestern Scotian Shelf), right whales feed on diapausing Calanus finmarchicus at depths that make visual predation extremely difficult, if not impossible (Baumgartner \& Mate 2003). During the fall and early winter, right whales likely continue to feed on deep stocks of diapausing Calanus finmarchicus in the Gulf of Maine (fall data from M. F. Baumgartner unpubl.). It is only during the late winter and early spring in the shallow habitats of the western Gulf of Maine (Cape Cod Bay and Massachusetts Bay) that right whales likely compete directly with zooplanktivorous fish for Pseudocalanus spp., Centropages typicus, and Calanus finmarchicus (Mayo \& Marx 1990, DeLorenzo Costa et al. 2006). Despite the lack of direct competition in right whale habitats for most of the year, higher abundances of herring could certainly reduce the overall abundance of Calanus finmarchicus in the Gulf of Maine and thereby affect right whale productivity. However, other fish that feed on Calanus finmarchicus have been abundant during the decline of herring (e.g. sand lance; Kenney et al. 1996), so despite shifts in community composition, it is unclear whether overall fish consumption of Calanus finmarchicus has changed dramatically. Moreover, herring are considered to have recovered by the late 1990s (Overholtz \& Friedland 2002), and right whale calf production in the late 2000s was particularly high (Pettis 2009).

\begin{abstract}
Acknowledgements. We are indebted to the following people for the loan of equipment and assistance in both the field and in the laboratory: captain and crew of the NOAA ship 'Albatross IV', M. Taylor, D. Mountain, B. Mate, M. Swartz, M. Patrician, and visual observers I. Biedron, R. Dore, H. C. Esch, S. Gaylord, N. Gilles, E. Josephson, B. Lentell, N. Lysiak, S. Mussoline, J. Nicolas, R. Pace, M. Phillips, D. Potter, S. Quinn, C. Tremblay, and E. Vu. Funding for this study was provided by NOAA National Marine Fisheries Service, Office of Naval Research Marine Mammals and Biology Program, the WHOI Ocean Life Institute, and the WHOI John E. and Anne W. Sawyer Endowed Fund. We dedicate this work to the memory of our good friend and colleague, John Nicolas, who will be sorely missed.
\end{abstract}

\section{LITERATURE CITED}

Batchelder HP (1985) Seasonal abundance, vertical distribution, and life history of Metridia pacifica (Copepoda: Calanoida) in the oceanic subarctic Pacific. Deep-Sea Res A 32:949-964

> Baumgartner MF (2003) Comparisons of Calanus finmarchicus fifth copepodite abundance estimates from nets and an optical plankton counter. J Plankton Res 25:855-868

Baumgartner MF, Fratantoni DM (2008) Diel periodicity in both sei whale vocalization rates and the vertical migration of their copepod prey observed from ocean gliders. Limnol Oceanogr 53:2197-2209

> Baumgartner MF, Mate BR (2003) Summertime foraging ecology of North Atlantic right whales. Mar Ecol Prog Ser 264:123-135

Baumgartner MF, Cole TVN, Campbell RG, Teegarden GJ, Durbin EG (2003a) Associations between North Atlantic right whales and their prey, Calanus finmarchicus, over diel and tidal time scales. Mar Ecol Prog Ser 264: 155-166

Baumgartner MF, Cole TVN, Clapham PJ, Mate BR (2003b) North Atlantic right whale habitat in the lower Bay of Fundy and on the SW Scotian Shelf during 1999-2001. Mar Ecol Prog Ser 264:137-154

Baumgartner MF, Van Parijs SM, Wenzel FW, Tremblay CJ, 
Esch HC, Warde AM (2008) Low frequency vocalizations attributed to sei whales (Balaenoptera borealis). J Acoust Soc Am 124:1339-1349

Beare D, McKenzie E (1999) Continuous plankton recorder data and diel vertical migration in stage V and VI Calanus finmarchicus: a statistical analysis. Fish Oceanogr 8(Suppl 1): 126-137

Bollens SM, Frost BW (1989) Zooplanktivorous fish and variable diel vertical migration in the marine planktonic copepod Calanus pacificus. Limnol Oceanogr 34:1072-1083

Bollens SM, Frost BW, Thoreson DS, Watts SJ (1992) Diel vertical migration in zooplankton: field evidence in support of the predator avoidance hypothesis. Hydrobiologia 234: 33-39

> Bost CA, Zorn T, Le Maho Y, Duhamel G (2002) Feeding of diving predators and diel vertical migration of prey: king penguins' diet versus trawl sampling at Kerguelen Islands. Mar Ecol Prog Ser 227:51-61

Campbell RG, Wagner MM, Teegarden GJ, Boudreau CA, Durbin EG (2001a) Growth and development rates of the copepod Calanus finmarchicus reared in the laboratory. Mar Ecol Prog Ser 221:161-183

Campbell RG, Runge JA, Durbin EG (2001b) Evidence for food limitation of Calanus finmarchicus production rates on the southern flank of Georges Bank during April 1997. Deep-Sea Res II 48:531-549

CETAP (1982) A characterization of marine mammals and turtles in the mid- and north Atlantic areas of the US outer continental shelf. Cetacean and Turtle Assessment Program, Final Report. Bureau of Land Management, Washington, $\mathrm{DC}$

Dagg MJ (1985) The effects of food limitation on diel migratory behaviour in marine zooplankton. Arch Hydrobiol Beih Ergebn Limnol 21:247-255

Dagg MJ, Frost BW, Newton JA (1997) Vertical migration and feeding behavior of Calanus pacificus females during a phytoplankton bloom in Dabob Bay, US. Limnol Oceanogr 42:974-980

Dandonneau Y, Neveux J (1997) Diel variations in in vivo fluorescence in the eastern equatorial Pacific: an unvarying pattern. Deep-Sea Res II 44:1869-1880

Davis CS, Gallager SM, Berman MS, Haury LR, Strickler JR (1992) The video plankton recorder (VPR): design and initial results. Arch Hydrobiol Beih Ergebn Limnol 36: $67-81$

> Davis CS, Gallager SM, Marra M, Stewart WK (1996) Rapid visualization of plankton abundance and taxonomic composition using the video plankton recorder. Deep-Sea Res II 43:1947-1970

Dawidowicz P, Pijanowska J, Ciechomski K (1990) Vertical migration of Chaoborus larvae is induced by the presence of fish. Limnol Oceanogr 35:1631-1637

> DeLorenzo Costa A, Durbin EG, Mayo CA (2006) Variability in the nutritional value of the major copepods in Cape Cod Bay (Massachusetts, USA) with implications for right whales. PSZNI: Mar Ecol 27:109-123

> De Robertis A, Jaffe JS, Ohman MD (2000) Size-dependent predation risk and the timing of vertical migration in zooplankton. Limnol Oceanogr 45:1838-1844

Durbin EG, Gilman SL, Campbell RG, Durbin AG (1995a) Abundance, biomass, vertical migration and estimated development rate of the copepod Calanus finmarchicus in the southern Gulf of Maine during late spring. Cont Shelf Res 15:571-591

> Durbin EG, Campbell RG, Gilman SL, Durbin AG (1995b) Diel feeding behavior and ingestion rate in the copepod Calanus finmarchicus in the southern Gulf of Maine during late spring. Cont Shelf Res 15:539-570
Emsley SM, Tarling GA, Burrows MT (2005) The effect of vertical migration strategy on retention and dispersion in the Irish Sea during spring-summer. Fish Oceanogr 14:1 $61-174$

Falkenhaug T, Tande KS, Semenova T (1997) Diel, seasonal and ontogenetic variations in the vertical distributions of four marine copepods. Mar Ecol Prog Ser 149:105-119

Fiksen O, Carlotti F (1998) A model of optimal life history and diel vertical migration in Calanus finmarchicus. Sarsia 83:129-147

> Flinn RD, Trites AW, Gregr EJ, Perry RI (2002) Diets of fin, sei, and sperm whales in British Columbia: an analysis of commercial whaling records, 1963-1967. Mar Mamm Sci 18: 663-679

Gliwicz MZ (1986) Predation and the evolution of vertical migration in zooplankton. Nature 320:746-748

Graeve M, Albers C, Kattner G (2005) Assimilation and biosynthesis of lipids in Arctic Calanus species based on feeding experiments with a ${ }^{13} \mathrm{C}$ labeled diatom. J Exp Mar Biol Ecol 317:109-125

> Greene CH, Pershing AJ (2004) Climate and the conservation biology of North Atlantic right whales: the right whale at the wrong time? Front Ecol Environ 2:29-34

Hays GC (1995) Ontogenetic and seasonal variation in the diel vertical migration of the copepods Metridia lucens and Metridia longa. Limnol Oceanogr 40:1461-1465

> Hays GC (2003) A review of the adaptive significance and ecosystem consequences of zooplankton diel vertical migrations. Hydrobiologia 503:163-170

> Hays GC, Proctor CA, John AWG, Warner AJ (1994) Interspecific differences in the diel vertical migration of marine copepods: the implications of size, color, and morphology. Limnol Oceanogr 39:1621-1629

Hays GC, Kennedy H, Frost BW (2001) Individual variability in diel vertical migration of a marine copepod: why some individuals remain at depth when others migrate. Limnol Oceanogr 46:2050-2054

Herman AW (1988) Simultaneous measurement of zooplankton and light attenuance with a new optical plankton counter. Cont Shelf Res 8:205-221

Herman AW (1992) Design and calibration of a new optical plankton counter capable of sizing small zooplankton. Deep-Sea Res A 39:395-415

Hirche HJ (1996) Diapause in the marine copepod, Calanus finmarchicus-a review. Ophelia 44:129-143

Hjort J, Ruud JT (1929) Whales and plankton in the North Atlantic. Rapp P-V Réun Cons Perm Int Explor Mer 56: $5-123$

Huntley M, Brooks ER (1982) Effects of age and food availability on diel vertical migration of Calanus pacificus. Mar Biol 71:23-31

Kawamura A (1974) Food and feeding ecology in the southern sei whale. Sci Rep Whales Res Inst 26:25-144

Kenney RD, Wishner KF (1995) The South Channel Ocean Productivity Experiment. Cont Shelf Res 15:373-384

Kenney RD, Hyman MAM, Owen RE, Scott GP, Winn HE (1986) Estimation of prey densities required by western North-Atlantic right whales. Mar Mamm Sci 2:1-13

Kenney RD, Payne PM, Heinemann DW, Winn HE (1996) Shifts in northeast shelf cetacean distributions relative to trends in Gulf of Maine/Georges Bank finfish abundance. In: Sherman K, Jaworski NA, Smayda TJ (eds) The Northeast Shelf ecosystem: assessment, sustainability, and management. Blackwell Science, Boston, MA, p 169-196

Laney SR, Letelier RM, Abbott MR (2005) Parameterizing the natural fluorescence kinetics of Thalassiosira weissflogii. Limnol Oceanogr 50:1499-1510 
Lorenzen CJ (1966) A method for the continuous measurement of in vivo chlorophyll concentration. Deep-Sea Res 13:223-227

Mayo CA, Marx MK (1990) Surface foraging behavior of the North Atlantic right whale, Eubalaena glacialis, and associated zooplankton characteristics. Can J Zool 68: 2214-2220

Miller CB, Crain JA, Morgan CA (2000) Oil storage variability in Calanus finmarchicus. ICES J Mar Sci 57:1786-1799

Ohman MD (1990) The demographic benefits of diel vertical migration by zooplankton. Ecol Monogr 60:257-281

> Ohman MD, Runge JA (1994) Sustained fecundity when phytoplankton resources are in short supply: omnivory by Calanus finmarchicus in the Gulf of St. Lawrence. Limnol Oceanogr 39:21-36

Ohman MD, Frost BW, Cohen EB (1983) Reverse diel vertical migration: an escape from invertebrate predators. Science 220:1404-1407

Overholtz WJ, Friedland KD (2002) Recovery of the Gulf of Maine-Georges Bank Atlantic herring (Clupea harengus) complex: perspectives based on bottom trawl survey data. Fish Bull 100:593-608

Payne PM, Wiley DN, Young SB, Pittman S, Clapham PJ, Jossi JW (1990) Recent fluctuations in the abundance of baleen whales in the southern Gulf of Maine in relation to changes in selected prey. Fish Bull 88:687-696

Pettis H (2009) North Atlantic Right Whale Consortium annual report card (01 November 2007-30 April 2009). Report to the International Whaling Commission Scientific Committee, SC/61/BRG11

Schilling MR, Seipt I, Weinrich MT, Frohock SE, Kuhlberg AE, Clapham PJ (1992) Behavior of individually-identified

Editorial responsibility: Edward Durbin, Narragansett, Rhode Island, USA sei whales Balaenoptera borealis during an episodic influx into the southern Gulf of Maine in 1986. Fish Bull 90: $749-755$

Shepard ELC, Ahmed MZ, Southall EJ, Witt MJ, Metcalfe JD, Sims DW (2006) Diel and tidal rhythms in diving behaviour of pelagic sharks identified by signal processing of archival tagging data. Mar Ecol Prog Ser 328:205-213

Tarrant AM, Baumgartner MF, Verslycke T, Johnson CL (2008) Differential gene expression in diapausing and active Calanus finmarchicus (Copepoda). Mar Ecol Prog Ser 355:193-207

Thomas AC, Townsend DW, Weatherbee R (2003) Satellitemeasured phytoplankton variability in the Gulf of Maine. Cont Shelf Res 23:971-989

Winn HE, Goodyear JD, Kenney RD, Petricig RO (1995) Dive patterns of tagged right whales in the Great South Channel. Cont Shelf Res 15:593-611

Wishner K, Durbin E, Durbin A, Macaulay M, Winn H, Kenney R (1988) Copepod patches and right whales in the Great South Channel off New England. Bull Mar Sci 43: 825-844

- Wishner KF, Schoenherr JR, Beardsley R, Chen C (1995) Abundance, distribution and population structure of the copepod Calanus finmarchicus in a springtime right whale feeding area in the southwestern Gulf of Maine. Cont Shelf Res 15:475-507

Zaret TM, Kerfoot WC (1975) Fish predation on Bosmina longirostris: body-size selection versus visibility selection. Ecology 56:232-237

- Zaret TM, Suffern JS (1976) Vertical migration in zooplankton as a predator avoidance mechanism. Limnol Oceanogr 21:804-813

Submitted: June 23, 2010; Accepted: November 10, 2010

Proofs received from author(s): January 27, 2011 